\title{
隣接するコープタウンと公的分変住宅団地におけるコミュニティ形成の 動向と特性に関する研究 \\ STUDY ON TENDENCY AND CHARACTERISTIC OF FORMING COMMUNITY IN BOTH NEIGHBORINING COOPERATIVE TOWN AND PUBLIC HOUSING COMPLEX FOR SALE
}

\author{
川岸梅和*, 神谷宏治** \\ Umekazu KAWAGISHI and Koji KAMIYA
}

\begin{abstract}
This study intends to clarify the change of 2 points in time from estimation of the dwellers' side basing on the questionnaire surveys executed for dwelles of both the same cooperative town and the neighboring common public housing complex for sale over 2 times in 1987 and 1997. At first arranging the change of 2 points in time of activity at the management society, the group of stairs or residential building and the circle, the arranging the change of 2 points in time of both participating realities and estimation of activity in housing complex of men's and women's dwellers over 21 years old, we investigated about the role and points which would fulfill forming community of the method of cooprative town by grasping the present conditions and tendency of cooperative town through comparing the 2 cases. As a result, we clarified the tendency and characteristics of forming community in making dwelling environment by the method of cooperative town.
\end{abstract}

Keywords : co-operative housing, community, residents' participation, living environment, activity in housing complex, leisure activity コーポラティブ住宅, コミュニティ形成, 居住者参加, 居住環境, 団地内活動, 余暇活動

\section{1.はじめに}

不特定多数の住宅需要者が直接参加し自主的な活動を基盤とした 集合住宅の建設やコミュニティづくりを目指したコーポラティブ・ ハウジングは, 1970年代前半から民間組織を中心に芽生えはじめた。

1975年以降, 民間組織の活動に加えて, 大阪府企業局（1977年・ 事業参加），住宅・都市整備公団（1978年・同），東京都住宅供給 公社（1982年・同）等の公共企業がコーポラティブ・ハウジングを 手掛ける展開が生まれた。

ここ20年来, 全国各地で実現したコーポラティブ住宅は, 約300 事例, 総戸数約6000戸であり, 概ね20～30戸単位のプロジェクトが 大多数である。それらは, 中, 高層住宅では 1 棟, また低層住宅で は数棟程度の単位で実施されているものが多い。この程度の規模は, 住民相互が顔見知りで親しい関係を保ち得る範囲であり，コミュニ ティの基礎単位とも言われ，コーポラティブ住宅の調査事例 '·"1・111 でも良好なコミュニティ形成が裏付けられている。

しかし，これらの事例の場合，建設規模が小さいために集会室， 庭，プレイロット，駐車場など共用部分の充実は求めがたく，同時 に点的に建設される為一定の広がりのある住環境づくりという面で は必ずしも十分とは言い難い。

また, 一般的に現状のコーポラティブ方式の住宅ブくりは, プラ
ンブくりのエネルギーが概ね住戸・住棟に集中する傾向にあること は否定できないといえよう。

従って, 如何にして住戸 · 住棟レベルの計画から街区レベルにま で計画対象を広げていくかが大きな課題となっていた。

そこで，10２0戸ないし30戸の基礎単位では充足できない共用空 間を全グループが共有することによって充実させようという考え方 が生まれた。

そして，基礎単位グループと集合したグループ群が，個と全体の 問題として，参加者自らが市民的自覚に基づいて協同して「集合的 住環境（住戸外部及び近隣）づくり」を行っていくという考え方も 生まれた。

$$
\text { これがコープタウン構想である。 }
$$

コープタウン方式では, 各グループが先ずグループ間で事業を進 める上での基本的なルールを確認し合い，グループごとに参加者が 自らの住戸内の計画・設計を行うと共に，全体としての調整を図り ながら段階構成的な合意形成を行い，調和のとれた快い生活環境亡 豊かなコミュニティを持つ「集合的住環境（住戸及び近隣）」を創 っていく事になる。

同時に，建設規模の拡大により，コミュニティ施設を初めとする 各種の共用施設の充実や，近隣住民との親しみやすい開かれたコミ
$*$ 日本大学生産工学部建築工学科 助教授・工修

** 日本大学生産工学部建築工学科 教授・工修
Assoc. Prof., Dept. of Architecture, College of Industrial Technology, Nihon Univ., M. Eng.

Prof., Dept. of Architecture, College of Industrial Technology, Nihon Univ., M. Eng. 
ユニティ形成なども可能に成ってくるといえよう。

一方，公的分譲住宅団地では，「個別的住環境（個々の住居）」や

「集合的住環境（住戸外部及び近隣）」は，事業主体の公的機関が 行うため, 住宅需要者の個別的・集合的住環境に対する個人的な意 思は, 大阪府住宅供給公社や熊本県住宅供給公社等で行わ扎た二段 階供給方式（需要者参加型住宅の試み）を除いて、当初全く生かす ことは不可能である。

従って，個別的・集合的住環境は画一的な状況に陥りがちであり 住宅需要者は入居後初めて近所付き合いが始まるためコミュニティ 活動が住宅団地内で行わ活性化するのに時間がかかるといえよ う。

そこで, 本研究では既に完成し入居しているコープタウン及び, それと隣接した公的分譲住宅団地社1) 居住者に対するアンケート調 査（1987年及び 1997年）を基に，居住者側からの評価を整理し， 1987年と1997年の 2 時点の変化等を検討し，コープタウンと公的分 譲住宅団地の現状と傾向を把握し，コープタウン方式のコミュニテ イ形成に果たす役割とその問題点についての基礎的知見を種々の活 動や近所づきあいの状㳘より得ようとするものである。

本研究の特徵としては, 次のような点が挙げられる。

（1）コープタウンと公的分譲住宅団地各々の現状の評価が可能と なる。
（2）コープタウンと公的分譲住宅団地各々の 2 時点の変化を明ら かにすることができる。

（3）コープタウン方式による個別的・集合的住環境づくりにおけ るコミュニティ形成の特性を, 隣接する公的分銥住宅団地の状況と 比較することにより明らかにすることができる。

（4）コープタウンと隣接する公的分譲住宅団地の居住者側からの 評価を検討し，各々の傾向と関連性を明らかにすることができる。

一方, 本研究に関する既往の研究として, 延藤安弘他によるコ一 ポラティブ住宅の計画原理に関する一連の研究 ${ }^{1}$ ， 住田昌二他によ るコーポラティブ方式による住宅建設に関する一連の研究 ${ }^{2 ?}$, 西村 一朗他によるコーポラティブ住宅における住生活に関する研究引， 城谷豊他によるコーポラティブ住宅居住者の余暇生活グループ化傾 向と住様式・住意識の連関に関する研究 ${ }^{4)}$, 野崎薰による集合住宅 における個別対応供給に関する研究ら”等がある。

しかし，これまでに，コープタウン方式のコミュニティ形成に果 たす役割と問題点に着目し, 同一のコープタウンと隣接する公的分 譲住宅団地において 2 時点の居住者調査を行い，各々の比較を通し てコミュニティづくりに関する関心度, 満足度等と団地内活動や管 理との関係性について検討した例は少なく，居住者の加㱓化，転入 居住者の増加等の状況の中で, それらの移り変わりを把握すること は今後のコーポラティブ・ハウジングへの提言となり, 本研究の独 自性もここにあると考える。

表 1 概念図

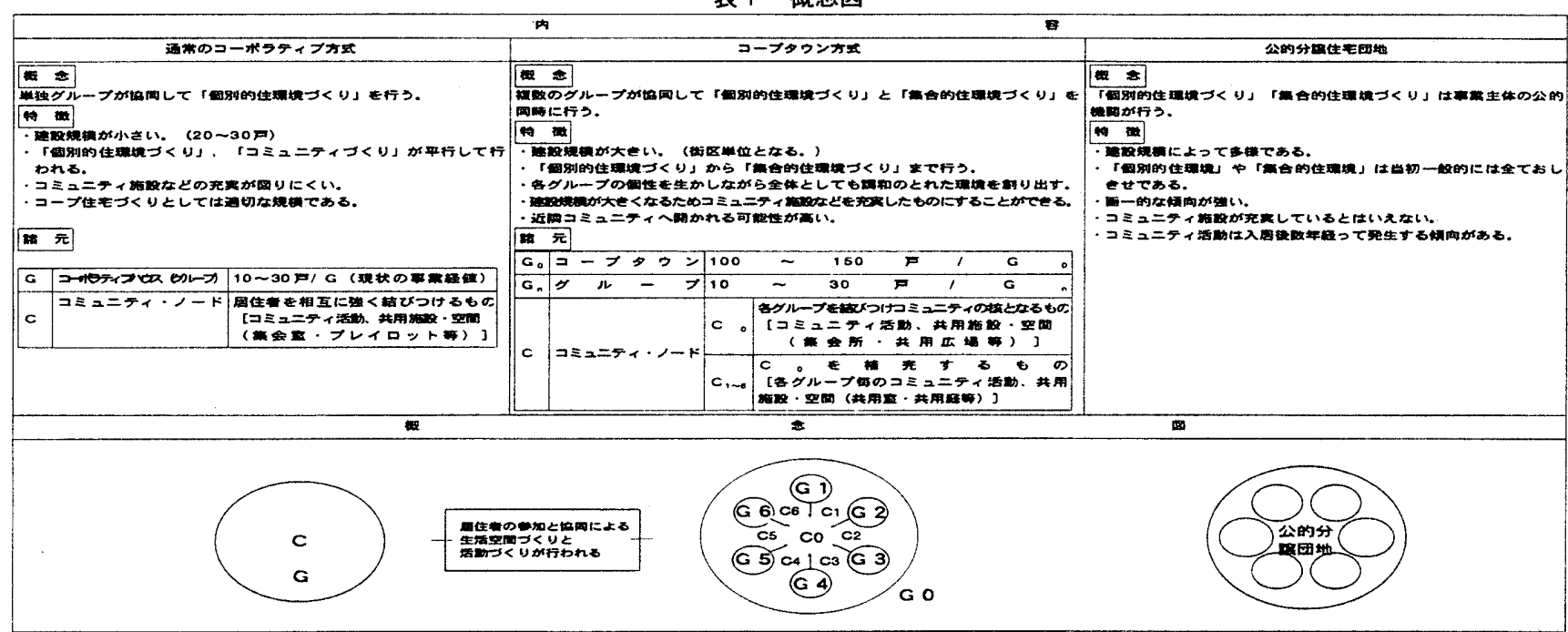

表 2 調査対象住宅団地の概要

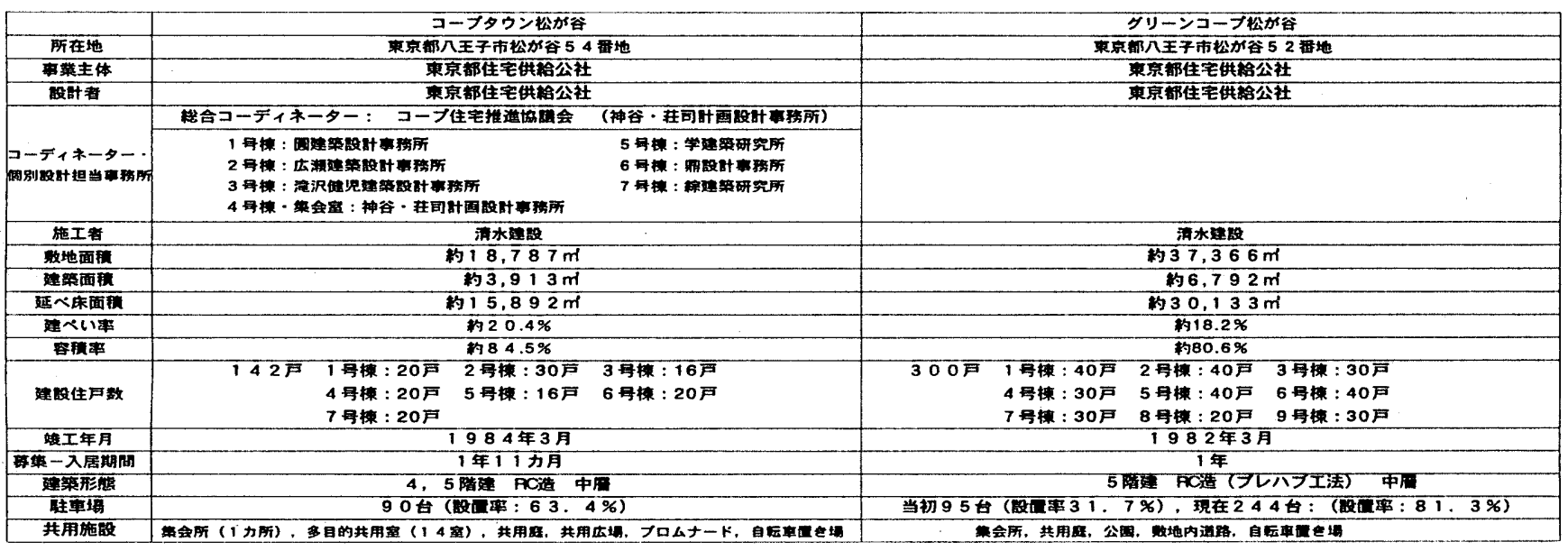




\section{2. 調查概要}

\section{1 . 調查対象}

本稿では, 多摩ニュータウン 18 住区, 東京都八王子市内に立地 するコープタウン松が谷（以下コープタウン）と, その北面に隣接 する公的分譲住宅団地グリーンコープ松が谷(以下グリーンコープ) としている。各々の概要は表 2 に, 配置図は図 1 に示すとおりであ る。

\section{2, 調査内容}

1987年，1997年共に，（1）管理組合，（2)階段・棟グループ, （3）サークル・クラブ，（4）個人, に対しヒアリングとアンケ 一ト調査を行った。ヒアリング調査は, 上記（1）（2）（3）を 対象に, 組織形態, 活動内容 - 頻度等で構成されており, アンケー 卜調查は（4）を対象に, 居住者の基礎的事項, 活動内容と参加状 況, 活動に対する評価, 近所付き合い人数等の内容で構成されてい る。

表 3 アンケート調查状況

\begin{tabular}{|c|c|c|c|c|}
\hline & \multicolumn{2}{|c|}{ コープタウン昖が谷 } & \multicolumn{2}{|c|}{ ダリーンコーブ松が谷 } \\
\hline 調查実施日 & 198.7 年 3 月 & 1997年3月 & 1987 年3月 & 1997 年 3月 \\
\hline 回収戸数 & $134 \bar{戸}$ & $92 \bar{F}$ & $63 \bar{戸}$ & $159 \bar{戸}$ \\
\hline 全市数 & $142 \bar{F}$ & $142 \bar{P}$ & $300 \bar{P}$ & $300 \bar{P}$ \\
\hline 回收率 & $\begin{array}{c}94 \% \\
(134 / 142)\end{array}$ & $\begin{array}{c}65 \% \\
(92 / 142)\end{array}$ & $\begin{array}{c}21 \% \\
(63 / 300)\end{array}$ & $\begin{array}{c}53 \% \\
(159 / 300)\end{array}$ \\
\hline 21 歳以上男珄回答数 & $115 \curlywedge$ & 77 人 & $55 \lambda$ & 145 人 \\
\hline 21 祡以上女性回答数 & $141 \lambda$ & 87 人 & $61 \lambda$ & $172 人$ \\
\hline
\end{tabular}

なお，本稿では研究の第 1 報として，1987年及び1997年の 2 回に わたり実施したヒアリング調査及び男女21歳以上の居住者に対する アンケート調査を基に，1987年と1997年の 2 時点の比較を通して， コープタウンと隣接した公的分譲住宅団地のコミュニティ形成の動 向と特性について報告を行う。

\section{3.コープタウン, グリーンコープ居住者の動向}

1997年の男女21歳以上に対するアンケート調査の有効回答数の 内, 転入居住者（図 2）の割合は, コープタウンよりグリーンコー プの方が高く 2 事例共に年齢構成は上昇する傾向が見られる。1997 年においては51歳以上の占める割合が高くなり，コープタウンの男 性は23\%から57\%へ，女性は $18 \%$ から40\%へ，グリーンコープの男 性は $18 \%$ から46\%へ，女性は20\%から29\%へと変化している。

転入居住者の占める割合の高いグリーンコープは，コープタウン に比べ男女共50歳以下の占める割合が高いと言えよう。

\section{4. 管理組合}

4. 1、管理組合の組織形態（図 4 ・図 5 )

雨団地共, 規約で定めた団地管理組合があり，理事会のメンバー が中心となり全体的な運営を行っている。2 時点において大きな変 化は見られないものの, 現在では時代の変化に対応した組織形態に なっているといえよう。

コープタウンでは，1987年には居住者の情報交換やコミュニティ 活動の一環として行わ抽いたCA T Vづくりが，その中心的担い 手であった子供達やその親達の減少により，1997年には行われてお らず，CA T V委員会が無くなっている。理事会の役員数は両団地 共変化はないが, 役割分担が細分化されてきている。両団地共他団

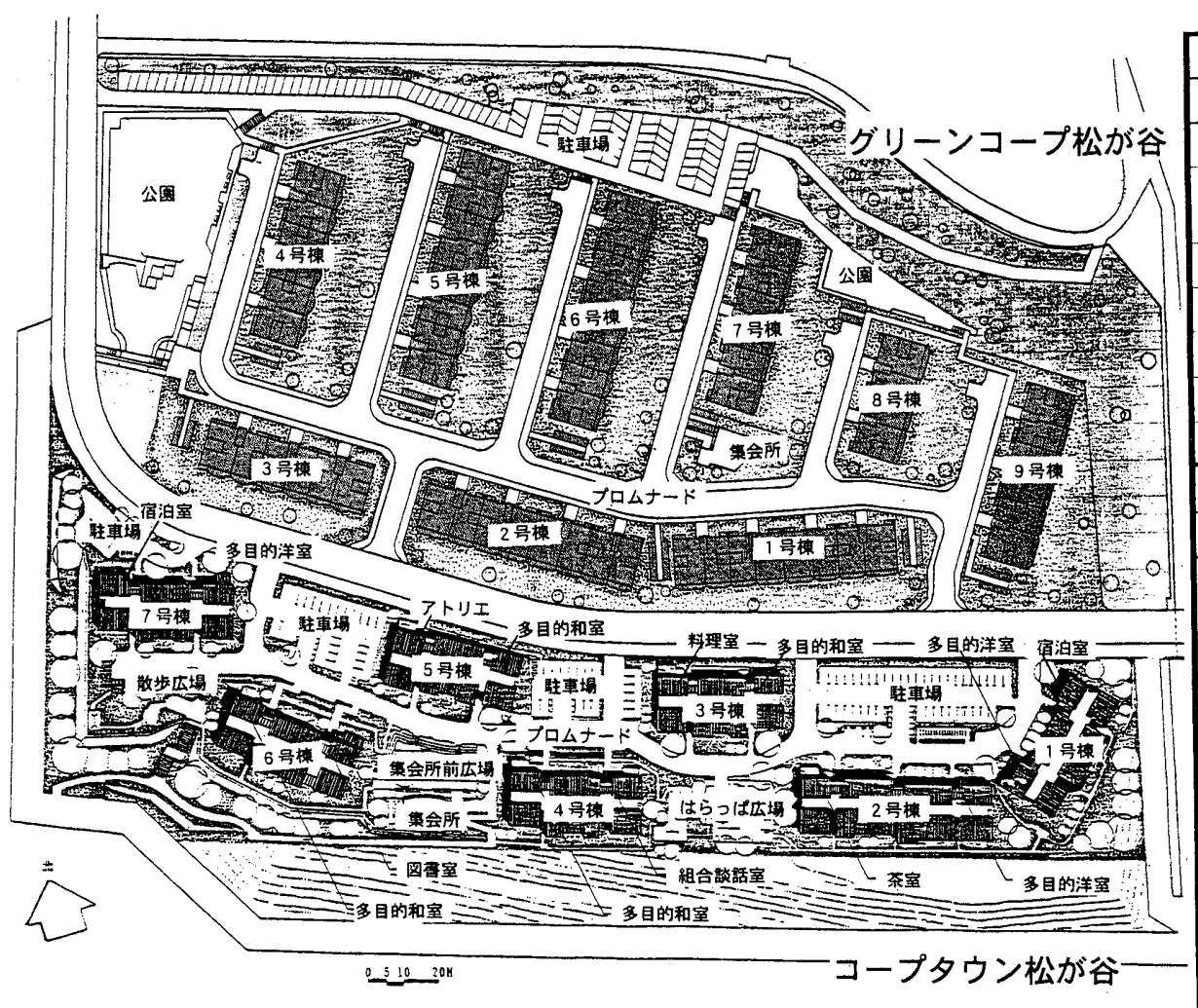

図 1 調査対象住宅団地の配㯰図

\begin{tabular}{|c|c|}
\hline \multicolumn{2}{|c|}{ グリーンコーブ松が谷 } \\
\hline 共用施設 & 施設規模 \\
\hline 集会所 & $130 \mathrm{~m}$ \\
\hline $\begin{array}{l}\text { グループコモン } \\
\text { (緑地, その他) }\end{array}$ & 約 $16,986 \mathrm{~m}^{\prime}$ \\
\hline 広場（公園） & 約 $2,927 \mathrm{~m}$ \\
\hline 步行者道路・路地 & 約 $7,755 \mathrm{~m}$ \\
\hline$\exists ミ$ 置き場 & 3 力所 \\
\hline 自転車䨵き場 & 9 力所 \\
\hline 駐車場 & 244 台 \\
\hline \multicolumn{2}{|c|}{ コープタウン松が谷 } \\
\hline 共用施設 & 施設規模 \\
\hline $\begin{array}{c}\text { 多目的共用室 } \\
\text { 平均 }\end{array}$ & $\begin{array}{c}234.09 \mathrm{~m} \\
16.72\left(\mathrm{~m}^{\prime} \mathrm{y} \text { 室 }\right) \times 14 \text { 室 }\end{array}$ \\
\hline 集会所 & $103.57 \mathrm{~m}$ \\
\hline $\begin{array}{l}\text { グループコモン } \\
\text { (緑地, その他) }\end{array}$ & 約 $8,453 \mathrm{~m}$ \\
\hline 広場（公園） & 約 $1,550 \mathrm{~m}^{\prime}$ \\
\hline 步行者道路 - 路地 & 約 $2,955 \mathrm{~m}$ \\
\hline$\exists \equiv$ 置き場 & 4 力所 \\
\hline 自転車置き場 & $\begin{array}{c}15 \text { 力所 } \\
\text { (各階段室脇) }\end{array}$ \\
\hline 駐車場 & 90 台 \\
\hline
\end{tabular}


地との対応（松が谷連絡協議会）を行う役割が明確になると共に， コープタウンでは, 単年度の管理組合費の運用を行う会計と, メン テナンスや大規模修繥に対応する長期積立金の運用を行う会計や阪 神・淡路大震災を契機として防火・防災の役割が設けられている。

\section{2. 管理組合活動（表 4)}

コープタウンでは, 共同管理運営活動の中でも自主管理活動に関 する項目や頻度はグリーンコープに比べ多く行われ，2 時点におけ る継続性もみられる。

しかし，CATV委員会活動は，CATVの番組づくりの主体的 な担い手であった子供達が加歯した為，1997年時点では活動を行っ ていない。近隣余暇活動（行事, 親睦等）では, 納涼大会（地域主 催）, 餅つき大会, 囲碁大会は継続的に行われているが, クリスマ ス会は C A T V 委員会と同様の理由で1997年時点では行われていな い。

一方, グリーンコープでは1997年時点の近隣余暇活動（行事, 親 睦等）で，歴代理事長琹親会や敬老食事会等，特定の居住者を対象 とした項目が見られ，居住者の誰もが参加できる活動は1987年に比 ベ減少している。

\section{5. 階段・棟グループ}

\section{1. 階段・棟グループの組織形態}

コープタウンでは， 7 棟各々に棟部会があり，グリーンコープで は階段毎に階段連絡委員会があり，活動を行っている。

両団地共, 組織形態は 2 時点において変化はみられない。

\section{5．2．階段・棟グループ活動（表 5 ）}

コープタウンでは，1987年には各棟とも活発に行われていた協同 管理運営活動や近隣余暇活動（行事，親睦等）が，1997年には減少 している。しかし，棟別会議や清掃など自主管理・運営に関する活 動は継続して1997年でも行われている。

一方，グリーンコープでは，1987年，1997年の 2 時点共に近隣余 昵活動（行事，親睦等）は行われておらず，理事会からの連絡を行 うことが主な活動である。また1987年に一部の階段連絡委員会が行 つていた階段会議や階段の清掃などは，1997年では全く行われてい ない。

\section{6. サークル}

6. 1.サークル活動（非営利）（表 6)

コープタウンでは，1987年には12あった非営利のサークル数は 1997年には 7 に減少しているが，活動頻度は1987年で約28.6回/月， 1997年で約32.0回/月であり，活動頻度は増加している。

コープタウンでは居住者の誰もが気軽に参加できる活動が活発に 行われていると言えよう。

一方グリーンコープでは，1987年，1997年共に非営利のサークル 活動は全く行われていない。

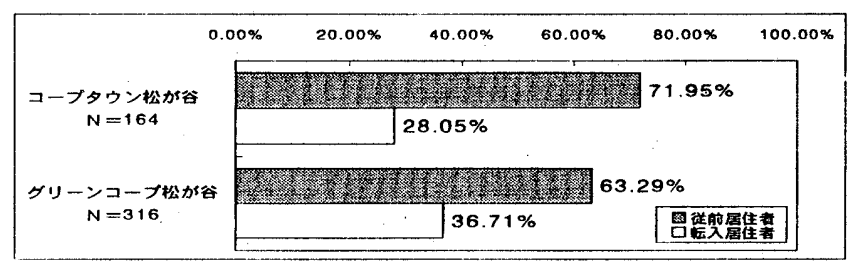

図 2 従前居住者・転入居住者の割合
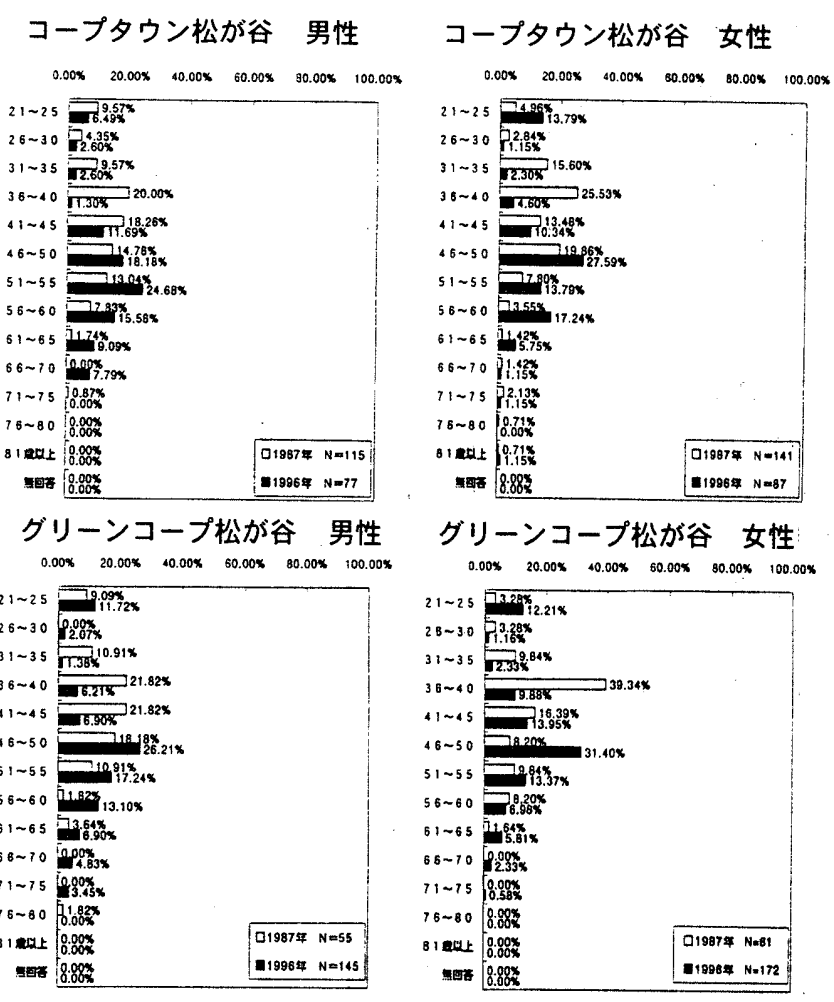

グリーンコープ松が谷 女性

0.00\% 20.00\% $40.00 \times \quad 60.00 \times \quad 80.00 \%$ 100.00\% $2 1 \sim 2 5 \longdiv { 1 3 2 9 8 \times }$

$28 \sim 30$ Pri, is

$31 \sim 35$ 2.33\%:

$3 6 \sim 4 0 \longdiv { 9 . 8 8 8 } - 3 8 . 3 4 \times$

$41 \sim 45=16.39 x$

$46 \sim 50=820 \times 5 \times 1.40 \times$

$51 \sim 55=884 x$

$56 \sim 60 \nabla_{6.86 x}^{8.208}$

$6) \sim 65$ 13.6.8.

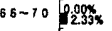

$71 \sim 75\left[\begin{array}{ll}0.00 x \\ 0.538\end{array}\right.$

$75 \sim 80) 8.08 \%$

81 .

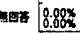

1967\% Ne81

図 3 年秢構成

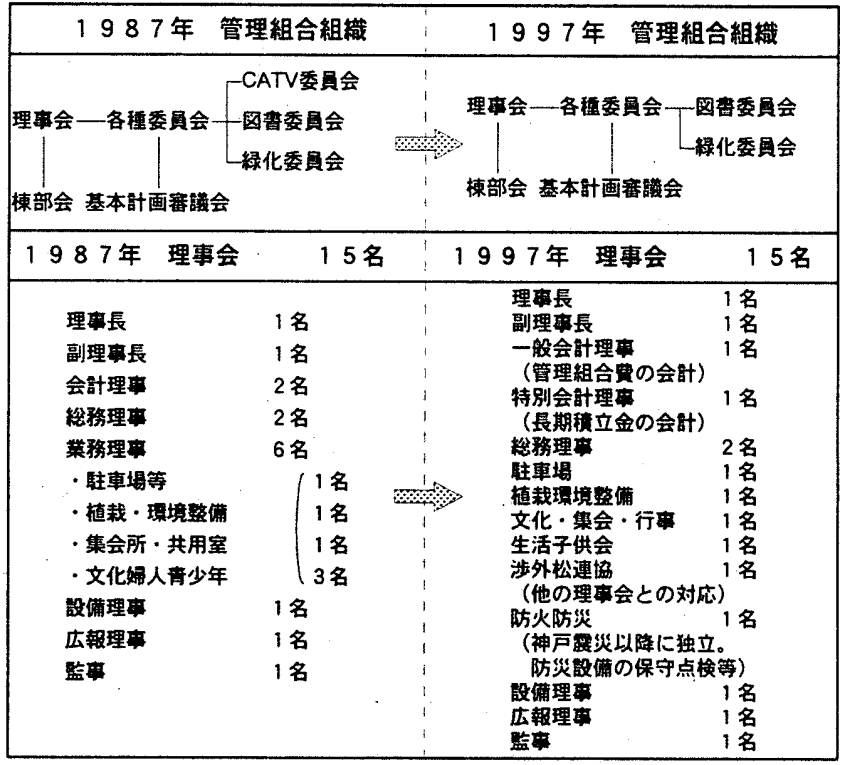

図 4 コープタウン松が谷管理組合搆成

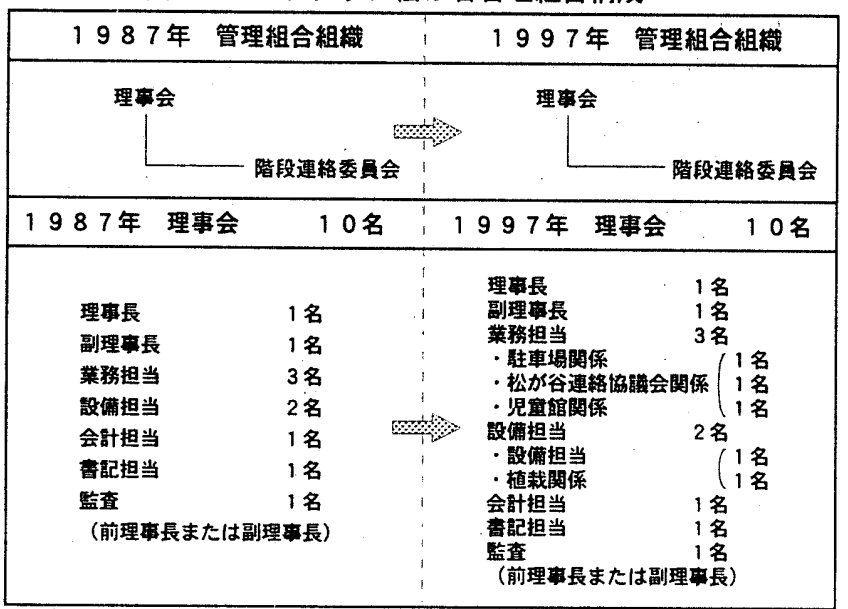

図 5 グリーンコープ松が谷管理組合構成 
表 4 管理組合活動

\begin{tabular}{|c|c|c|c|c|c|c|}
\hline & & 名称 & 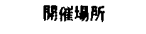 & 加人数 & 閒稚疑度 & 活绕時間 \\
\hline \multirow{14}{*}{1987} & \multirow{9}{*}{ 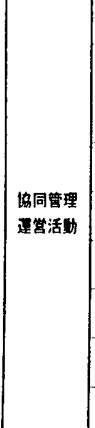 } & 㗭会 & 集会所 & $80 \sim 85$ 名 & 1回/年 & 時间 \\
\hline & & 理草会 & 集会听 & 15名 & 20 回/年 & 为2 時闻 \\
\hline & & 龱罡委员会 & 集会所 & 为20名 & 1 回/ 2 カ月 & 2 時间 \\
\hline & & 标化委员会 & 集会所 & 的 20 名 & 1 回/2カ月 & 2 時间 \\
\hline & & CATV委虽会 & 集会听 & 12名 & 2 回/月 & 3 時闻 \\
\hline & & 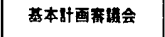 & 㥯会所 & 9 名 & 1 2回/月 & $4 \sim 5$ 封闻 \\
\hline & & 清得 & - & - & 1回/月 & - \\
\hline & & 是源回收 & - & - & 1 回/月 & - \\
\hline & & 俭化車量 & 团地全体 & - & 4 回/年 & - \\
\hline & \multirow{5}{*}{ 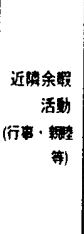 } & 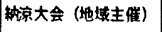 & 松が谷小学校投明 & 100 名 & 1 回/年 & 16 时凨 \\
\hline & & クリスマス会 & 集会所 & 料50名 & 1回/年 & 8書闻 \\
\hline & & 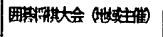 & 棒会所 & $50 \sim 60$ 名 & 1回/年 & 5 時闻 \\
\hline & & 䀠つき大会 & 集会防 & N1408 & 1 回/年 & 10 時間 \\
\hline & & 睡大會 & 集会所 & S20名 & 1回/年 & 10 时间 \\
\hline \multirow{12}{*}{1997} & \multirow{7}{*}{ 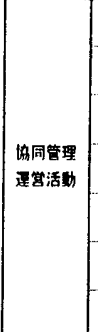 } & 稔会 & 集会所 & $70 \sim 80$ 名 & 1 回/ 年 & 2 時简 \\
\hline & & 理需会 & 集会所 & 15 名 & 20 回/年 & 约2 時闰 \\
\hline & & 图曾委员会 & 集会所 & 6 名 & 1回/ 2力月 & 2時用 \\
\hline & & 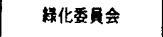 & 集会所 & 19 名 & 1回/ 2力月 & 2 時间 \\
\hline & & 相大こみ回収 & - & - & 1 回/ 年 & - \\
\hline & & 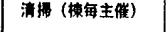 & 各埋共用鄐分 & - & 1回/月 & - \\
\hline & & 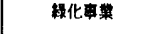 & 团地全体 & - & 6 回/年 & 为2 明間 \\
\hline & \multirow{5}{*}{ 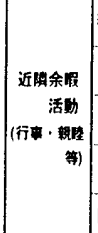 } & 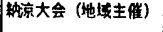 & 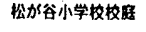 & $40 \sim 50$ 名 & 1回/年 & 8期闻 \\
\hline & & 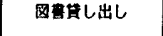 & 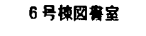 & 6名 & 1 回/ 兑 & - \\
\hline & & ソフトホール大会 & 昖加谷小学校技庭 & 90 名 & 1 回/ 年 & 6 時间 \\
\hline & & 明つを大会 & 点会所的広场 & $60 \sim 708$ & 1 回/年 & 3時间 \\
\hline & & 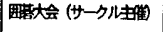 & 3昂搛和室 & - & 1 回/年 & - \\
\hline
\end{tabular}

\begin{tabular}{|c|c|c|c|c|c|c|}
\hline & & 名林 & 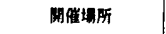 & 加人 & 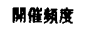 & 活数時间 \\
\hline \multirow{10}{*}{1987} & \multirow{6}{*}{$\begin{array}{l}\text { 地同管理 } \\
\text { 遇営活活 }\end{array}$} & 格会 & 昖力唂高校 & 200 名 & 1回/年 & 为 2 時间 \\
\hline & & 理束会 & 策会所 & $9 \sim 10$ 名 & 24 回/年 & 的 4 時阔 \\
\hline & & 晴段連格委員会 & 集会听 & 30 名 & 1回/月 & 1.5 时间 \\
\hline & & 䩸り & 各畨周边 & 全是鹤施 & 2回/年 & 3 时間 \\
\hline & & 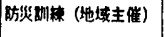 & 集会所とその周边 & 米250名 & 1 回/年 & 3時间 \\
\hline & & バザー大会 & 集会所とモの周辺 & 全员参加 & 1 回/ 年 & 半日 \\
\hline & \multirow{4}{*}{ 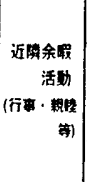 } & ソフトボール大会 & 昖が谷高校 & $50 \sim 808$ & 1回/年 & 半日 \\
\hline & & 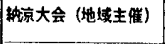 & 松加谷小学校技后 & - & 1回/年 & - \\
\hline & & 睤つを大会 & 筆会所と周辺 & 1008 & 1回/年 & 4 時閪 \\
\hline & & 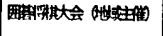 & 集会所 & $50 \sim 808$ & 1 回/ 年 & 5 時間 \\
\hline \multirow{10}{*}{1997} & \multirow{6}{*}{ 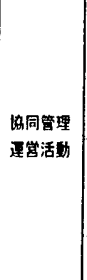 } & 㴔会 & 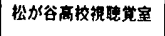 & 200 名 & 1回/年 & $2 \sim 2.5$ 時间 \\
\hline & & 理舅会 & 集会所 & 9 名 & 24 回/年 & 的 2 时周 \\
\hline & & 陼段遺制委員会 & 轓会所 & 308 & 1 回/月 & 1.5 時间 \\
\hline & & 版り & 各樏周讱 & 2008 & 3 回/ 年 & 2時周 \\
\hline & & 明大こみー䜤処理 & - & - & 1 回/年 & 4時闻 \\
\hline & & 陼段清据·自完車整理 & 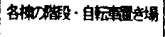 & 200 名 & 1 回/ 年 & 2 時間 \\
\hline & \multirow{4}{*}{ 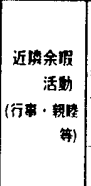 } & 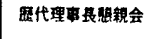 & 集会所 & 15名 & 1 回/年 & 2 時同 \\
\hline & & 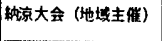 & 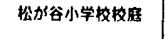 & - & 1回/年 & 8時闌 \\
\hline & & 眀つき大会 & 蓞会听 & 30 名 & 1回/年 & 2 時闻 \\
\hline & & 敬老食軎会 & 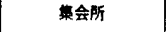 & 30 名 & 1 回/年 & 2 時間 \\
\hline
\end{tabular}

表 5 階段ないし棟グループ活動

\begin{tabular}{|c|c|c|c|c|c|c|}
\hline & & 名弥 & 闌叙细所 & 加人数 & 阙脽绪度 & 活里明間 \\
\hline \multirow{38}{*}{1987} & \multirow{8}{*}{1 号橉 } & 捷别会致 & 6 昼梀和室 & 内20人 & 1 回/年 & 2 時闻 \\
\hline & & 塂を芼大会 & 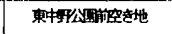 & 281 & 1回/年 & $2 \sim 3$ 時间 \\
\hline & & $t \rightarrow l i s-\pi<1023 x$ & 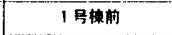 & $15 \lambda$ & 1 回/年 & $1 \sim 2$ 時间 \\
\hline & & 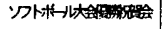 & 6 号梀共用室 & 23 人 & 1 回/年 & 4 時间 \\
\hline & & パーペキュー大会 & 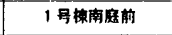 & 371 & 1 回/ 年 & $3 \sim 4$ 時图 \\
\hline & & 研つを大会 & 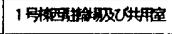 & $27 \lambda$ & 1回/年 & $10 \sim 12$ 時闌 \\
\hline & & 涞掅 & - & - & 住民の自主 & - \\
\hline & & 新年会 & 策会所 & $43 \curlywedge$ & 1 回/年 & 4 時闹 \\
\hline & \multirow{8}{*}{2 号榑 } & 楝别会比 & 製会所 & N301 & 0.5 回/月 & 2 時間 \\
\hline & & 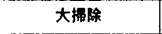 & 暏段每 & $7 \sim 8 \lambda$ & 2 回/年 & 2 時阔 \\
\hline & & 陼段洲撋 & 各止行了 & 当番制 & 1 2回/河 & 0.5 時間 \\
\hline & & ₹杊り & 2 号揳周辺 & $3 \sim 4$ 人 & 1 回/ 2カ月 & 3 時周 \\
\hline & & 生湾活娌 & 简段木ール & $7 \sim 8$ 剽保度 & 1 回/因 & 1 蛙間 \\
\hline & & 新年会 & 慗会所 & $\$ 45 \sim 50$ 人 & 1 回/ 年 & $3 \sim 4$ 時间 \\
\hline & & 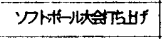 & 2号棟箕用窒 & $12 \sim 13 \lambda$ & 1 回/年 & $1.5 \sim 2$ 時间 \\
\hline & & 跑面教室 & 共用室 (洋室) & $x 4 \sim 5 \lambda$ & 1 回/泪 & $2 \sim 3$ 時周 \\
\hline & \multirow{3}{*}{3 量茠 } & 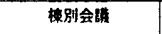 & 熟会所 & 約 $16 \lambda$ & 0.5 回/月 & 2 時阔 \\
\hline & & 溥严 & 井用室及ひその周讱 & 当鲁制 & $1 \sim 2$ 回/月 & 0.5 時间 \\
\hline & & 新年会 & 集会所 & 2201 & 1 回/年 & 3 時周 \\
\hline & \multirow{7}{*}{4 号槏 } & 梀別会证 & 6 号菓和室 & 2201 & 1回/月 & 2 時间 \\
\hline & & 整事会 & 5 号獭アトリエ & $4 \lambda$ & 1 回/月 & 2 时間 \\
\hline & & 大擩除 & 階段及び 4 号濑周讱 & 201 & 1 回/月 & $2 \sim 3$ 時閐 \\
\hline & & 并用室の洲檽 & 4 号梀和宾 & 当番制 & 1 回/遇 & 0.5 時周 \\
\hline & & 忘年金 & 恝会所 & 4 号筫居住粕 & 1 回/年 & 3 時成 \\
\hline & & 牧み会 & 共用室·笨会所 & $3 \sim 10$ 家族 & $4 \sim 5$ 回/ 年 & 2 時阔 \\
\hline & & 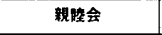 & 4 年棉多目的并用至 & 4 号摷主䋨 & 1 回/月 & 1 時间 \\
\hline & \multirow{4}{*}{5 年棈 } & 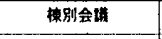 & 践会所 & 201 & 0.5 回/月 & 2 時阔 \\
\hline & & 清捂 & 䧄段及ひ自元車雷を㘿 & 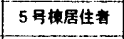 & 回/2力月 & 1 時間 \\
\hline & & ボーリンダ大会 & よみうリラント & 225 & 1回/年 & 2 時間 \\
\hline & & 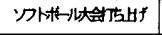 & 集会所 & 饬 201 & 1回/年 & 3 時阔 \\
\hline & \multirow{5}{*}{6 号榑 } & 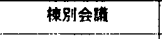 & 6号楼和室 & 301 & 1回/月 & 1 時间 \\
\hline & & 淉檽 & 陵段及ひ共用空 & 自由加 & 1回/月 & 1 時用 \\
\hline & & 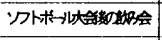 & 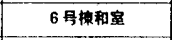 & 6 号棟居住告 & 1回/年 & 1時阔 \\
\hline & & バーベキュー大会 & 公圈 & 6 号揀居住查 & 1回/年 & $2 \sim 3$ 时阙 \\
\hline & & 新年会·忘年会 & 蹅会所 & 6 每梖居住普 & 1回/年 & 3 時国 \\
\hline & \multirow{3}{*}{7 号橉 } & 樯别会睛 & 7号柏多目的共用至 & 籸 20 人 & 0.5 回/月 & 2 時闻 \\
\hline & & 㴋擐 & 猎段及ひ共用室 & *10人 & 1回/月 & 1 時国 \\
\hline & & 忘年会 & 集会防 & $\$ 40 \lambda$ & 1回/年 & 3.5 時䦎 \\
\hline \multirow{23}{*}{1997} & \multirow{3}{*}{1 号搛 } & 棟别会错 & 共用室 & 171 & 6回/年 & 1.5 時間 \\
\hline & & 陼段泳掦 & 隌段 & 4人 & 1 回/月 & 0.5 時周 \\
\hline & & 新年会 & - & 281 & 1 回/年 & - \\
\hline & \multirow{5}{*}{2 号橧 } & 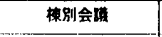 & 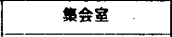 & 301 & 6 回/年 & 2 時间 \\
\hline & & 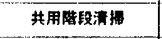 & 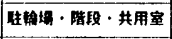 & 301 & 1２回/年 & 1 明周 \\
\hline & & 新年会 & 䔩会所 & $50 \sim 60 \lambda$ & 1 回/年 & 3 封同 \\
\hline & & 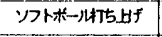 & 㗱会所 & $30 \lambda$ & 回/年 & 3 野闻 \\
\hline & & 莗取り後盟光 & フロムナート & $30 \sim 40 \curlywedge$ & 3 回/ 年 & 0.5 時周 \\
\hline & 3 号榑 & 樈别会湴 & 楅会所又は共用室 & $15 \lambda$ & 6 回/年 & 2 時间 \\
\hline & \multirow{4}{*}{4 号樯 } & 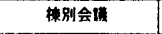 & 集会所 & $17 \lambda$ & 1回/月 & 2 明周 \\
\hline & & 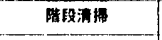 & 路段 & $15 \lambda$ & 1回/月 & 1.5 時周 \\
\hline & & 忘年会 & 集会所 & $50 \lambda$ & 1回/年 & 4 時自 \\
\hline & & 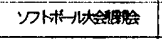 & 共用室 & $30 \lambda$ & 1回/年 & 3時間 \\
\hline & \multirow{4}{*}{5 号樯 } & 撞別会明 & 型用室 & $17 \lambda$ & 1回/月 & 2 時間 \\
\hline & & 畦线要员会 & 昔用垔 & $2 \curlywedge$ & 1 回/ 年 & 5 時間 \\
\hline & & 䧄段沙清 & 隌段・井用 & 161 & 1回/月 & 1 時阙 \\
\hline & & 竞槸会 & 雔会听 & $40 \lambda$ & 1 回/年 & 2 時闻 \\
\hline & \multirow{2}{*}{6 号棈 } & 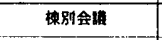 & 6昌䅦和室 & $15 \lambda$ & 1回/月 & 2 時阔 \\
\hline & & 嘴段㴋灀 & 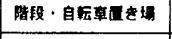 & 101 & 1 回/月 & 时间 \\
\hline & \multirow{4}{*}{7 号樯 } & 棟別会粗 & 和空 & $12 \sim 13 \lambda$ & 6 回/年 & 2 時需 \\
\hline & & 生湓 & 洋案 & $4 \lambda$ & 1 回/进 & 0.5 时间 \\
\hline & & 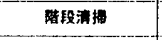 & 俻段 & $7 \sim 8$ 人 & 1 回/月 & 0.5 时間 \\
\hline & & 新年会 & 車会所 & 35 人 & 1 回/年 & 4 时周 \\
\hline
\end{tabular}

\section{コープタウン松が谷}

\begin{tabular}{|c|c|c|c|c|c|c|}
\hline & & 名称 & 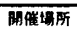 & 加人数 & 閑催粼度 & 活娌时间 \\
\hline \multirow{5}{*}{1987} & \multirow{2}{*}{ 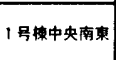 } & 锴段金梢 & 霜金所 & 101 & 2 回/月 & 1.5 时閐 \\
\hline & & 擆段の湆拥 & 各陵段 & 舟 10 & 1 回/年 & 1 时成 \\
\hline & 1 号柫中央北西 & 阹段の消擩 & 各幚段 & 内 101 & 1圆/年 & 1 时周 \\
\hline & \multirow{2}{*}{6 号楝北西 } & 隌段会请 & 萬会所 & $10 \lambda$ & 2回/月 & 1.5 时間 \\
\hline & & 量格 & 道直 & 内 39 人 & 逜宜 & 通宜 \\
\hline 1997 & - & $\overline{-}$ & - & $=$ & - & - \\
\hline
\end{tabular}


表 6 サークル活動（非営利）

\begin{tabular}{|c|c|c|c|c|}
\hline & 名称 & 活動场所 & 参加人数 & 活䥼制度 \\
\hline \multirow{13}{*}{1987} & 蚛会 (エフレ゙イス & 慗会所 & 20 名 & 1 回/ 週 \\
\hline & 囲基クラブ & 5 号㨂和室 & 26 名 & 7 回/年 \\
\hline & 楄み物教室 & 1 号棟洋室 & 20 名 & 4 回/月 \\
\hline & 婨み物同好会 & 集会所 & 7名 & 1 回/䢙 \\
\hline & 描画の会 & 5 号槏アトリエ & 7 名 & 4 回/月 \\
\hline & スケッチの会 & 2.号棟洋室 & 5 名 & 2 回/月 \\
\hline & 茶道同好会 & 2号棵余室 & 11名 & 1 回/週 \\
\hline & 前茶同好会 & 2 号棟杀室 & 12 名 & 2 回/月 \\
\hline & ケーキ作りの会A & 3 号楝料理室 & 8名 & 1 回/月 \\
\hline & ケーキ作りの会B & 3 号棟料理室 & 5 名 & 1 回/月 \\
\hline & 洋菓子铋署会 & 3号棟料理室 & 6名 & 1 回/月 \\
\hline & パンの会 & 3号㨂料理室 & 6 名 & 1 回/月 \\
\hline & 費道教窒 & 6 号棟和室 & 20 名 & 4 回/月 \\
\hline \multirow{7}{*}{1997} & 囲基クラフ & 5 号棟和室 & 15 名 & 1 回/週 \\
\hline & トリム体操 & 集会所 & 12 名 & 1 回/遇 \\
\hline & タンス & 集会所 & 30 名 & 1 回/週 \\
\hline & ジャスタンス & 粲会所 & 20 名 & 1 回/ 週 \\
\hline & |バンヒー二 (体暎) & 耖会所 & 80 名 & 2 回/遇 \\
\hline & 木彫り教室 & 1 号棟洋室 & 6 名 & 1 回/ 週 \\
\hline & 䜫道 & 2 号棟和室 & 20 名 & 1 回/ 週 \\
\hline
\end{tabular}

\section{コープタウン松が谷}

\begin{tabular}{|c|c|c|c|c|}
\hline & 名称 & 活動㛫所 & 加人数 & 活轨頛度 \\
\hline 1987 & - & - & - & - \\
\hline 1997 & - & - & - & - \\
\hline
\end{tabular}

グリーンコープ松が谷

\section{7. 個人}

7. 1. 活動に対する参加実態（図 6)

表 4，表 5，表 6 に示す活動に対し「1.積極的に参加している」 「2.仕事・時間の関係で無理もあるが, できるだけ参加している」 「3.人に誘われるので参加している」「6.規約上義務的に参加して いる」居住者について 1987年と1997年とを比較すると，2 事例の男 女ともに大幅に減少する傾向がみられる。

コープタウンはグリーンコープと比較すると減少率は小さく，そ の要因としては, 2 時点において継続性のみられる活動が管理組合, 棟グループ等で行われていることが挙げられる。

参加していない理由として，「仕事の都合上」「時間の関係」等 が挙げられており，また「団地の維持管理に関する活動には積極的 に参加しているが，その他の活動はほとんど参加していない」「集 会には時間の許す限り出席したいと思うが文化活動等には参加した ことがない」等がヒアリングで得られた。

一方，グリーンコープの参加していない理由としてにこのよな 活動があるかないかすら分からない」「活動がなく誘われることも ない」「希望するものがない」等がヒアリングで得られた。

また，コープタウンでは定住意識の有る男性，女性の参加率はグ リーンコープに比べ高い。

\section{活娌に対する镜加実態}

1. 程缊的に加している。

2. 仕事，時间の淮保で無理もあるが，できるだけ加している。

3. 人に糸われるのでた加している。

4. 闸心かないであまり加しない。

5. 全く興呠かないので加したことがない。

6. 規标上接的に加している。

7. その他

コープタウン松が谷 男性 コープタゥン松が谷 女性 $\begin{array}{lllll}0.00 \% & 20.00 \% & 40.00 \% & 60.00 \% & 80.00 \times \quad 100.00 \%\end{array}$ $0.00 \% \quad 20.00 \% \quad 40.00 \% \quad 60.00 \%$ \% $80.00 \% \quad 100.00 \%$

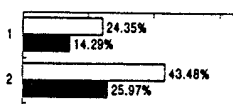

$3 \int_{1.30 \times}^{0.87 \times}$

4 $16.96 \times x_{10.48 \times}$

$5 \square_{16.94 x}^{6.96 x}$

${ }_{6} \square_{7.798} 17.38 \mathrm{x}$

$70.00 \%$

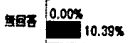

10.35\%

ーンコープ松が谷 男性

0.00\% 20.00\% 40.00\% 60.00\% 80.00\% 100.00\%

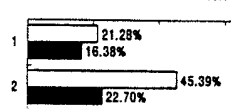

3 . $0.71 .72 \times$

+75.67\% $17.82 x$

$5 \stackrel{0.20 x}{10.42 \times}$

$6{ }_{12.645}^{23.40 x}$

$70.00 \%$

플.

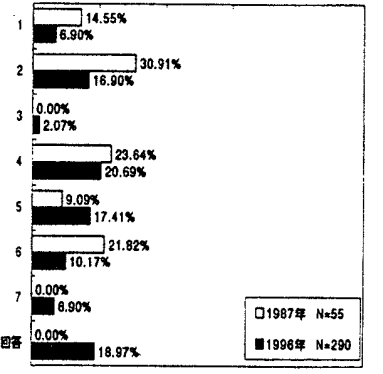

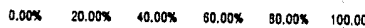

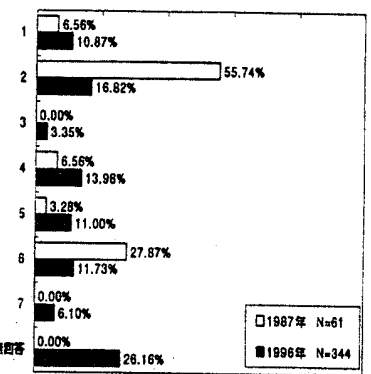

図 6 活動に対する参加実態

\section{活勤に対する融価}

1、非常に有意竦だと㕺えている。

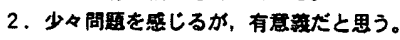

3. 悬義は認めているが個人的には四味がない。

4. 自分以外の問题なので全く興味がない

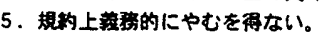

6. その他
コープタウン松が谷 男性

$\begin{array}{llllll}0.00 \times & 20.00 \times & 40.00 \times & 60.00 \times & 80.00 \times & 100.00 \times\end{array}$

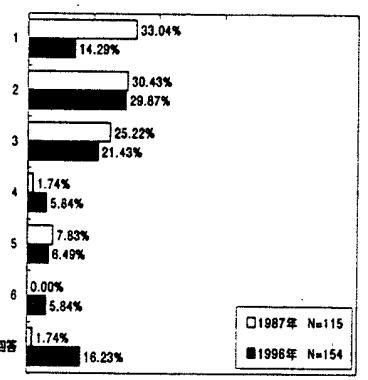

グリーンコープ松が谷 男性 0.00\% 20.00\% $\quad 40.00 \times \quad 60.00 \times \quad 80.00 \times \quad 100.004$

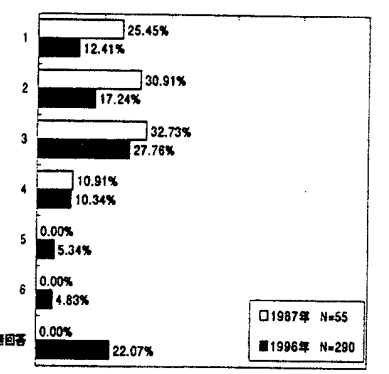

コープタウン松が谷 女性

0.00\% 20.00\% $\quad 40.00 \times \quad 60.00 \times \quad 80.00 \times \quad 100.00 \times$

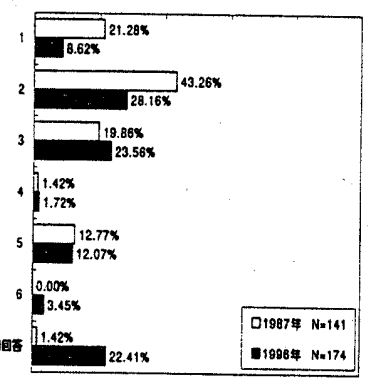

グリーンコープ松が谷 女性 $\begin{array}{lllll}0.00 \times & 20.00 \times & 40.00 \times & 60.00 \times & 80.00 \times \quad 100.00 \%\end{array}$

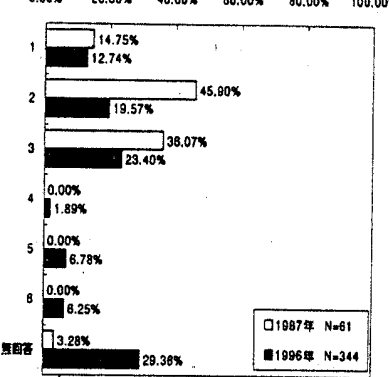

図 7 活動に対する評価 


\section{2. 活動に対する評価（図 7）}

表 4, 表 5，表 6 に示す活 動に対し，「1.非常に有意義だと考え ている」「2.少々問題を感じるが，有意義だと思う」と考えている 積極派の占める割合について，1987年と1997年とを比較すると， 2 事例共に活動に対する参加率と同様に大幅に減少する傾向がみられ る。

コープタウンはグリーンコープと比較して減少率は小さいが，七 アリングより「共通の関心事がなかなか無い」「高齢化に伴い，肉 体的負担が多い」と考えている居住者が僅かながら存在している。

一方グリーンコープではヒアリングより「意義の有無については 特に考えたことが無い」「活動内容を知らない」「活動があるかな いかすら分からない」等の意見が得られた。

また, コープタウンでは定住意識の有る男性, 女性の積極派はグ リーンコープに比べ高い。

\section{8. 共用部分の管理の担い手（表 7)}

コープタウン, グリーンコープにおける共用部分の管理の担い手 について1987年と1997年の 2 時点の変化をみると，コープタウンで は，「共用庭・通路等の清掃」が1987年では居住者ができる範囲の ことを自主管理で行い，それ以外のことは委託管理であったが， 1997年では全て委託管理となっている。また，「集会室（所）の清 掃，戸締まり」においては，1987年では担当役員や組合雇用の管理 人が行っていたが，1997年ではその一部の清掃を民間の専門業者に 委託するようになっている。10年を経て，自主管理から徐々に委託 管理へと変化しつつあるが，「階段・廊下等の清掃」「芝生・花壇 の手入れ」「樹木の日常的手入れ」等1997年現在でも多くのことが 自主管理で行われている。しかし，「高歯化に伴い，肉体的負担の 大きいものを委託したい」「体力的に重労働と感じられる」等, 加 齢化に伴い自主管理を負担に感じる居住者がいる事がヒアリングで 得られた。特に，樹木の管理が挙げられ，「高木の剪定等は，樹木 の知識を持った専門家に託したい」との意見が多く聞かれた。

一方, グリーンコープでは 2 時点での変化はみられない。

\section{9. 近所付き合いの状況（図 8)}

近所付き合いの人数における1987年と1997年の 2 時点の変化をみ ると,コープタウン・グリーンコープ共に 2 人以下の割合が減少し 7 人以上の割合が増加している。

その要因は，コープタウンの男性が1987年に比べ団地内の人や地 域の人との付き合いが増加していることと，グリーンコープの男性 が団地内の人との付き合いが増加していることにあると思われる。

\section{0 . まとめ}

本研究は, 隣接するコープタウンと公的分譲住宅団地居住者のア ンケート調查により男女 21 歳以上の評価と共に，居住環境づくりに おけるコミュニティ形成の要因として考えられる協同管理運営活 動，近隣余餟活動（行事・親睦等），近所付き合いの状況に関して 2 時点及び両事例の比較より把えたものである。その結果とヒアリ ング調査結果を要約すると以下のようになる。

1）種々の活動に対し参加し，意義を認める居住者は 2 事例共に減 少傾向がみられるが，コープタウンの減少率はグリーンコープに比
表 7 共用部分の管理の担い手
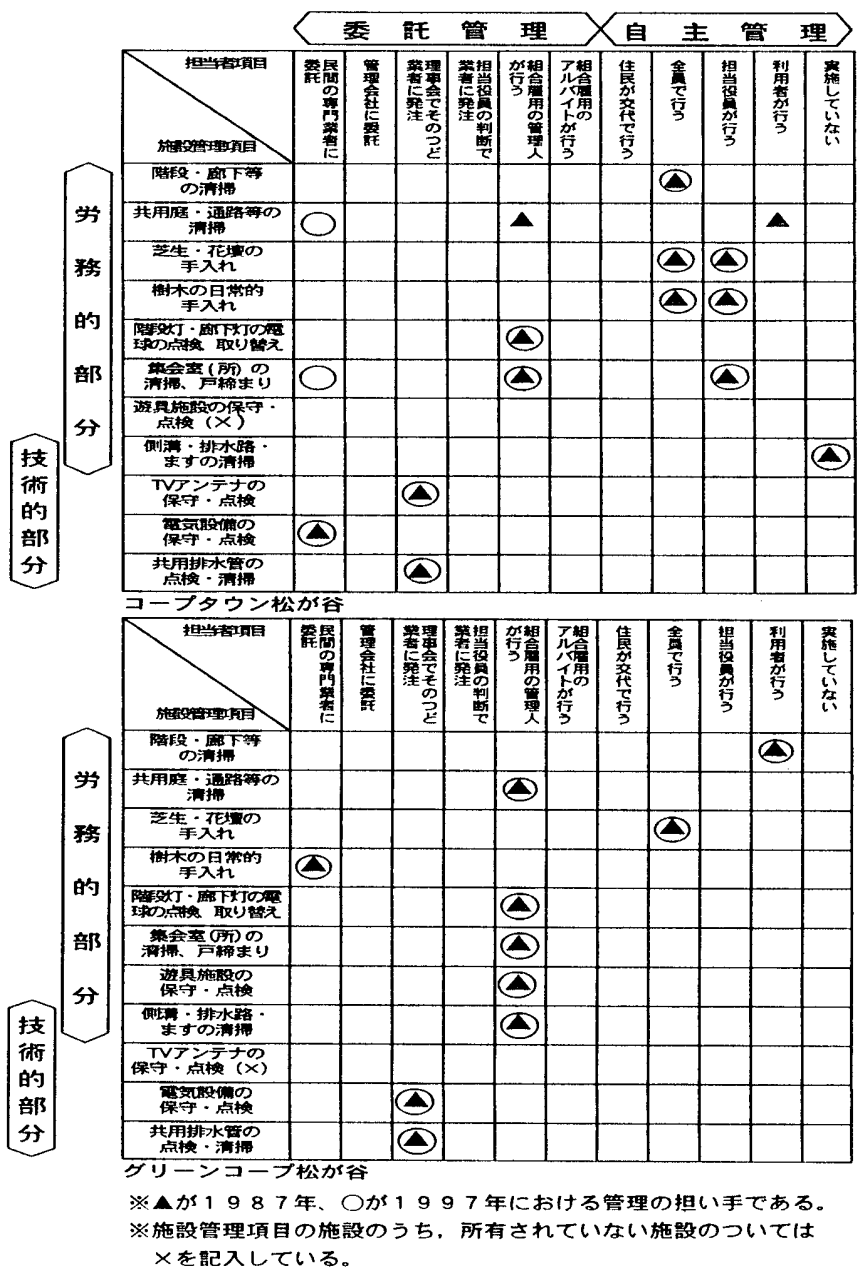

近所付き合いの人数

$\begin{array}{ll}\text { 1. 誰もいない } & 5.7 \sim 8 \text { 人 } \\ \text { 2. } 1 \sim 2 \text { 人 } & 6.9 \sim 10 \text { 人 } \\ \text { 3. } 3 \sim 4 \text { 人 } & 7.11 \text { 人上上 }\end{array}$

4. $5 \sim 6 \curlywedge$

コープタウン松が谷 男性 コープタウン松が谷 女性

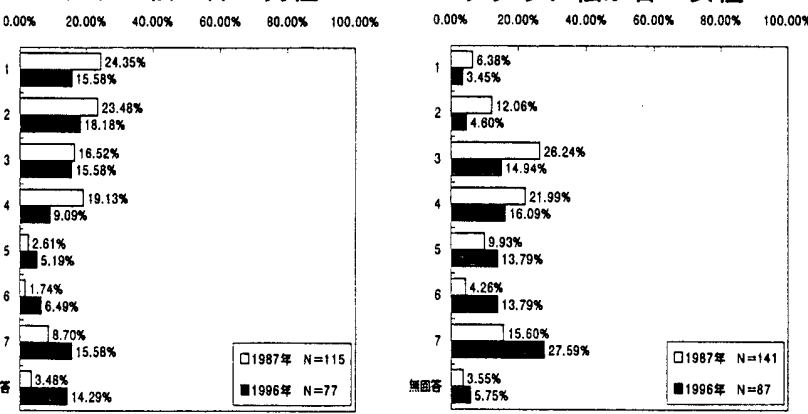

グリーンコープ松が谷 男性

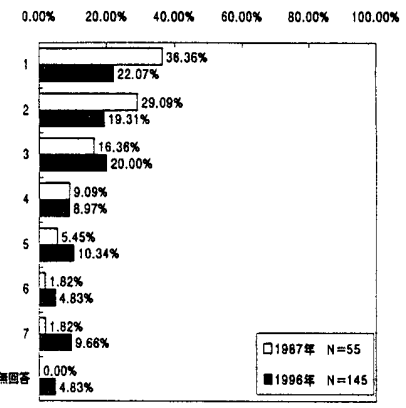

グリーンコープ松が谷 女性

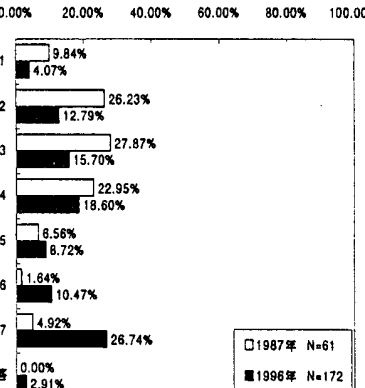

図 8 近所付き合いの人数 
ベ少ない。協同管理運営活動における自主管理, 棟グループ活動, サークル活動等, 項目数は減少しているが, 継続して活動が行われ ている事が要因であろう。一方グリーンコープは誰もが参加できる 活動は徐々に減少し, 居住者の参加意識も低く団地内の居住者同士 の交流の機会も少なく，コミュニティに対する意識低下を招いてい ると言える。

2) コープタウンにおける管理の担い手は, 徐々に自主管理項目が 委託管理項目に移行しつつある。加齢化による管理に対する意識の 変容は種々の活動に対し参加し, 意義を認める居住者に影響を及ぼ していると言えるが, 居住者の高齢化に対応した移行と言え, 今後 は自主管理活動の内容・頻度の更なる検討が望まれる。

3 ）近所付き合いの人数は，2事例共に経年の中で増加傾向がみら れる。その要因は男性の近所付き合いの状況を反映しており，コー プタウンでは団地内の人, 地域の人, グリーンコープでは団地内の 人との付き合いが増加している。

4) コープタウンのサークルの中で囲碁クラブやバンビーニ(体操) 等は, 近隣に開かれており，グリーンコープ居住者の参加がみられ る。また管理組合の活動でも居住者は地域主催の活動への積極的な 参加がみられると共に，コープタウン内で行われる行事にグリーン コープ居住者の参加がみられる。

5 ）グリーンコープ居住者のヒアリングでは，「コープ住宅をもつ と取り入れる考えを事業主体に持ってもらいたい」「コープタウン と比ベグループ活動, 文化活動が何も無く, つまらない老人団地に なりそう。」等の意見が得られた。コープタウン居住者の活動や様 相がグリーンコープ居住者に影響を与えつつあると思われる。

6) 種々の活動の果たす役割は, コープタウンとグリーンコープを では異なっている。コープタウンではコープ方式の特徵により，入 居以前より顔見知りとなり, かつ種々の活動を通してある程度良好 なコミュニティが育まれていると言えよう。居住者の入れ替わりゃ 年月の経過に伴う意識の低下の中でコミュニティを如何に持続して いくかが, 今後の問題点であると言える。一方, グリーンコープに おいては，入居時にはコミュニティは形成されておらず, 種々の活 動は入居後の良好なコミュニティの育成手段として担われるものと 考えられる。

7) コープタウンにおいて，協同生活のデメリットとして自主管理 活動等の役割負担の重さをあげる居住者が見られ, 良好なコミュニ ティを保つための 1 つの手段として居住者が容易に参加と協同がで きる活動とその役割負担のバランスをどの様にとっていくかが重要 な課題となるであろう。

今後は, 地域や住居形態が異なり, かつ隣接するコープタウンと 公的分譲住宅団地におけるコミュニティ形成の動向と特性について 考察を重ねたい。

尚, 本研究は平成 9 年度日本大学生産工学部建築工学科より研究 助成金を受けた。また，1987年，1997年の調査を行うにあたり御協 力をいただいたコープタウン松が谷, グリーンコープ松が谷の居住 者各位に謝意を表したい。

\section{注}

1) 本稿においては、隣接したコープタウンと公的一般分講住宅団地として 中層 4、 5 階建、住戸数 142 戸、プロムナードを軸に住榑がストリート 型配置され、集会所（１力所）の他に14室の多目的共用室が設けられた コープタウン松が谷と, その北面に隣接する中層 5 階建, 住戸数 300 戸,
住棟が亚列配置され，集会所（1カ所）が設けられたグリーンコーブ松 が谷を調查刘象にしている。

\section{本論文に関連する既発表文献}

I）川岸梅和, 神谷䆖治：企画者と参加者により結成されたグループにおけ るコミュニティ形成の移り変わりーコーポラティブ住宅におけるコミュ ニティ形成の動向と特性その 1 一、日本建築学会㖕囬系論文集第500咢, PP. 191 198, 1997. 10

II）川岸梅和、神谷宏治：民間企業主導により結成されたグループにおける コミュニティ形成の移り変わり,コーポラティブ住宅におけるコミュニテ 1 形成の動向と特性その 2 一, 日本建築学会計画系論文集第506号. PP. 119 126,1998.4

四）神谷宏治, 他：コーポラティブ・ハウジングに咸する研究その1〜そ の9, 日本建築学会大会学術講演梗概集, 1978 1982

神谷宏治、川岸梅和, 他 : コーポラティブ・ハウジングに関する研究 その10〜その30, 同, 1988〜1997

N) 神谷宏治, 川岸梅和：コーポラティプハウジングに関する研究、日本大

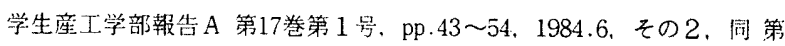
17 巻第 2 号. pp.29〜 40,1984.12, その 3 , 同第19巻第 1 号, pp.63〜 77. 1986.6、その 4, 同第22巻第 1 号, pp.125 141，1989.6

\section{参考文献}

1）延藤安弘，横川俊祐，古川智博：コーポラティブ住宅の㖕画研究として の方法的位置つけーユーコートの特質とその計画原理（1）一、日本建 築学会計画系論文報告集 第396 号, pp.12〜19，1989.2

延藤安弘, 横山俊祐, 古川智博：価值つくくりの計画としてみた個性的な 住戸平面の評価 ーューコートの特質とその計画原理 $(2)$ 一，同 第406 号, pp.87 98, 1989.12

福田由美子, 延藤安弘: 共用空間と集住生活の相互作用のプロセスの偊 価 ーユーコートの特質とその計画原理 (3) -, 同 第444号. pp.21〜 30. 1993.2

山田朋来，延滕安弘：集住環境生成過程における何俌つくりについての 考察 コーポラティブ住宅・あじろぎ横丁について、同第443咢, pp.41 $\sim 50,1993.1$

乾亭、延藤安弘、森永良丙：洒值づくりの計画プロセスにおける住み手 の計画側への役割の浸透ーユーコートの計画プロセスにおける住み手と コーディネーターの相互浸透性 1 一，同第446号，pp.53〜63.1993.4 乾亭，延藤安弘，箖永良丙：洒值つくりの計画プロセスにおけるコーデ イネーターの住み手側への立場の浸透一ユーコートの計画プロセスにお ける住み手とコーディネーターの相互浸透性 2-、日本建築学会計函系 論文集 第459号. pp.69〜77, 1994.5

森永良丙，延藤安弘，横山俊䌸：「状況つくり」の視点からみた参加型

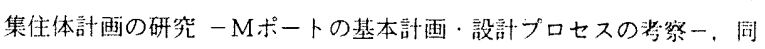
第478号, pp.69〜78. 1995.12

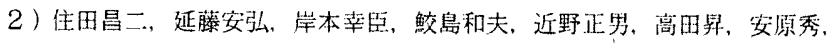
篠畸由紀子：コーポラティブカ式による住宅建設の研究 その1〜その 8, 日本建築学会大会学術講演梗概集，pp.1661～1676，1979.9

3 ) 西村一朗, 今井範子, 久保妙子：コーポラティブ住宅における住生活に 関する研究その 1 その 3 . 日本建築学会大会学術講演梗概集, pp. $193 \sim 198,1988.10$

4 ) 城谷豊、桜井康宏、武沢敏樹、橋本史一：コーポラティブ住宅居住者の 余睱生活グループ化傾问と住様式・住意識の連関に関する研究（その1） ～(その 3). 日本建筑学会大会学術溝演梗概集，pp.137 142. 1990. 10, (その 4$) \sim($ その 6$)$. 闰. pp.103〜108，1991.9

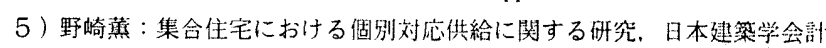
画系論文集第470 号, pp.63〜72.1995.4

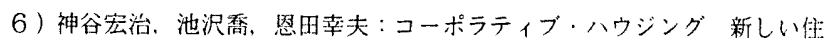
まいとコミュニティ, ダイヤモンド社, 1978.3

7 ) 神谷宏治, 池沢喬、延滕安弘, 中林由行：コーポラティプ・ハウジング, 鹿島出版会. 1988.3

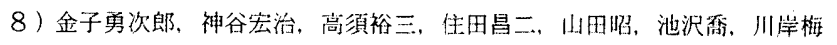
和. 石原知久: 大都市に批るコミュニティ形成に関する研究ーコーポ ラティブカ式についてー，（財）日本住宅総合センター, 1980.10

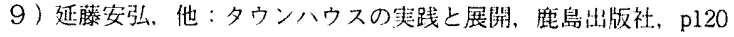

